\title{
Celebrity Role in Sarpol-e Zahab Earthquake in Iran 2017
}

\author{
Mohammad Heidari, PhD; Seyedeh Samaneh Miresmaeeli, MSc; and Neda Eskandary, \\ PhD student
}

$\mathrm{S}$ ome parts of western Iran, including Kermanshah province and especially Sarpol-e Zahab, were struck by 7.3 -magnitude earthquakes at 2148 hours on Sunday, November 13, 2017, ${ }^{1}$ which led to more than 483 deaths (237 men and 246 women) and approximately 10,000 injuries. About 70,000 people were homeless, and some villages were completely destroyed (Figure 1).

Celebrities played a significant role in helping the people of Sarpol-e Zahab, an Iranian city that was hit particularly hard. They established various campaigns for collecting supplies and cash donations for the victims, collaborated with Red Cross Red Crescent centers and other relief agencies for support, and offered their sympathy to the people and victims of Sarpol-e Zahab. This tremendous support and response motivated others to join in their efforts to raise money for the victims by sponsoring charity concerts, performing plays and activities for children, as well as holding an artwork auction.

Many of the most well-known celebrities are in the sports and entertainment industries, ${ }^{2}$ which are among the most popular celebrity types with people in the community. As well, celebrities are considered valuable resources in various social, political, cultural, and economics fields. ${ }^{2}$ After the Sarpol-e Zahab earthquake, many prominent celebrities came forward to help the people and victims.
For many of Sarpol-e Zahab, celebrity presence was uplifting and sparked new hope. The people felt more optimistic and were delightfully mesmerized by the number of celebrities who came forward after the devastation. The positive mood and morale among the relief workers by the celebrities' presence were also evident. Working alongside prominent celebrity figures inspired hope and confidence among Army and Red Cross Red Crescent relief workers who were present during the early hours of the earthquake and witnessed massive damage and devastation.

However, in some cases, the celebrity presence might have created some problems with interference during the relief process. For example, some relief supplies were randomly distributed, thereby many victims did not receive proper provision or care on a timely basis, and many items donated were not suitable or essential to some victim cases at hand, including medicines. Further, the focus on disaster relief and immediate care of the people deviated, with attention oftentimes placed on the celebrity and taking pictures ("selfies") during relief work efforts. As a result, people requiring immediate medical provision and care from health facilities and services did not receive the proper attention and care.

In crisis situations, actions can be more organized, integrated, and institutionalized. ${ }^{3}$ Further, celebrities can be provided with a kind of coherence and order for assistance while using their position of influence.

FIGURE 1

Sarpol-e Zahab Earthquake ${ }^{1}$

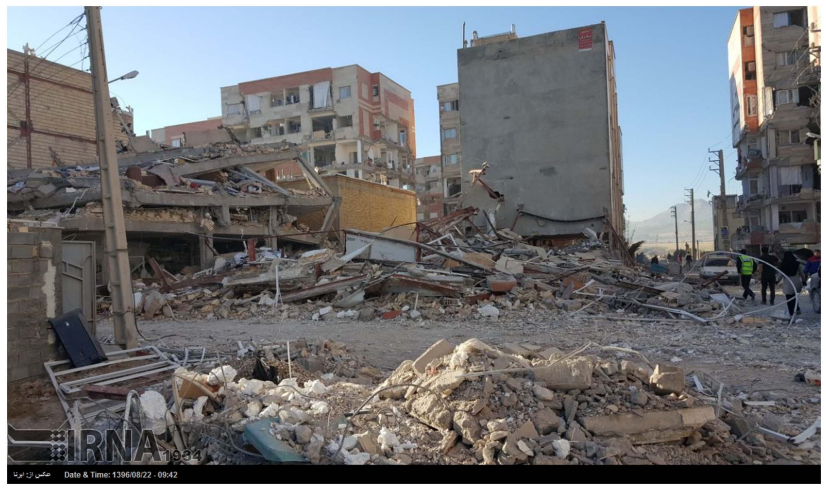

Photo courtesy of IRNA news: http://cdn.asriran.com/files/fa/news albums/572240/17084/resized/resized 763476 681.jpg 
It is suggested that celebrities help victims through civic organizations, such as charities, to distribute goods and collected items based on a needs assessment conducted by the relief organizations for the cash and non-cash aid. This gesture can increase the people's trust for responsible organizations, government, and relief agencies. Also, perhaps an intrinsic quality, most would be in agreement that celebrity presence has a way of alleviating people's ailments and psychological distress, especially during the recovery phase for people affected by a natural disaster. Celebrities communicate and sympathize with victims personally, uplifting their spirits and providing hope.

In summary, celebrities have a tremendous influence with setting up fundraisers and motivating people to volunteer and donate their time and money to help disaster victims, as well as partnering with relief agencies, such as Red Cross and Red Crescent centers, to provide facilities and distribute collected goods and supplies to charity organizations. During the Harvey storm, an American football player called on his supporters online via his website to donate cash to two local charity associations in Houston. Also, one Oscar-winning actor donated $\$ 1$ million to the American Red Cross, and another Oscar-winning actor contributed \$1 million to the newly established United Way Harvey Recovery Fund. ${ }^{4}$

\section{About the Authors}

Department of Medical and Surgical, School of Nursing and Midwifery, Shahrekord University of Medical Sciences, Shahrekord, Iran (Mr Heidari), Health Management and Economics Research Center, Iran University of Medical Sciences, Tehran, Iran (Ms Miresmaeeli); and Urbanism, School of Civil, Architecture and Art, Science and Research Branch, Islamic Azad University, Tehran, Iran (Ms Eskandary).

Correspondence and reprint requests to Seyedeh Samaneh Miresmaeeli, Health Management and Economics Research Center, Iran University of Medical Sciences, Tehran, Iran

(e-mail: s.miresmaeeli@gmail.com).

\section{Conflicts of Interest}

The authors declare that there are no conflicts of interest.

\section{REFERENCES}

1. Cambridge Dictionary. Celebrity. http:/dictionary.cambridge.org/dictionary/ english/ celebrity. Accessed January 30, 2018.

2. Driessens O. Celebrity capital: redefining celebrity using field theory. Theory Society. 2013;42(5):543-560.

3. Roy N. The Asian tsunami: Pan-American Health Organization Disaster Guidelines in Action in India. Prehosp Disaster Med. 2006;21(5):310-315.

4. United Way. Press release: United Way establishes national recovery fund to benefit areas affected by Hurricane Harvey. Published August 30, 2017. https://www.unitedway.org/the-latest/press/uw-establishes-recovery-fundto-benefit-areas-affected-by-harvey. Accessed September 25, 2018. 